\title{
The International Consequences of the 1979 U.S. Monetary Policy Switch: The Case of Switzerland
}

Georg Rich

\section{INTRODUCTION}

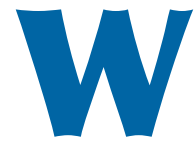

hen the news of a fundamental change in U.S. monetary policy hit the Swiss National Bank (SNB) in October 1979, its key officials welcomed the Fed's decision with noticeable sighs of relief. The SNB was pleased about the U.S. policy switch for two reasons. First, the Fed's unwillingness to take decisive action against inflation had complicated considerably the conduct of Swiss monetary policy. In particular, accelerating U.S. inflation had prompted worried international investors to sell dollar-denominated assets in exchange for other currencies such as Swiss francs. The ensuing sharp drop in the exchange rate of the U.S. dollar had upset the SNB's calculations and had undermined its efforts to achieve price stability without jeopardizing real growth of the domestic economy. Second, the SNB hoped that the Fed's conversion to monetary discipline would help to convince other monetary authorities of the need to achieve low inflation. As a matter of fact, the 1979 policy switch, combined with similar developments in Europe and other parts of the world, thoroughly transformed the global monetary landscape. Most central banks now regard low inflation as the primordial objective of monetary policy. The beneficial effect of this change in attitude has been a dramatic fall in inflation in most parts of the world. In what follows, I will examine the international consequences of the Fed's policy switch in light of Swiss experience.

\section{ACHIEVING PRICE STABILITY IN THE FACE OF A WEAK U.S. DOLLAR}

In the second half of the 1960s, Swiss inflation began to accelerate in line with the worldwide surge in prices. Despite a strong desire to stabilize prices, the SNB was powerless in curbing inflation as long as Switzerland insisted on maintaining a fixed exchange rate. Furthermore, as the postwar system of fixed exchange rates began to collapse, Switzerland faced massive inflows of speculative capital triggered by expectations about a substantial revaluation of the Swiss franc and other European currencies against the U.S. dollar. Since the SNB could sterilize at best a small portion of the attendant increase in its foreign exchange reserve, the capital inflows led to an excessive expansion in the money supply, adding fuel to the already serious inflation problem. Notably in 1971, the Swiss monetary base expanded enormously. ${ }^{1}$ Not surprisingly, the year-on-year inflation rate, measured in terms of consumer prices, shot up to a peak of 11.9 percent in December 1973. The Swiss public regarded this development as a major calamity. In the past, persistently high inflation had never arisen during peace-time.

A realignment of exchange rates in 1971 provided only temporary relief to Swiss authorities. Another incipient speculative assault at the beginning of 1973 forced the authorities to float the exchange rate of the Swiss franc. As a result, the SNB acquired the ability to combat inflation through a tight monetary policy. Under the

\footnotetext{
1 On average, it exceeded its previous year's level by 27.4 percent. See the appendix for the sources of the data used in this paper.
}

Georg Rich was the Chief Economist of the Swiss National Bank until his retirement in 2001. He is now an honorary professor and part-time lecturer at the University of Bern.

Federal Reserve Bank of St. Louis Review, March/April 2005, 87(2, Part 2), pp. 337-41.

(C) 2005, The Federal Reserve Bank of St. Louis. 
influence of Karl Brunner and other leading monetarists, it opted for a policy strategy of strictly controlling the money supply. The SNB was convinced that inflation was due largely to excessive money growth. For this reason, it decided to stabilize the monetary base at the level attained at the beginning of 1973. Toward the end of 1974, it adopted monetary targeting and allowed the money supply to increase again. At first, it announced annual growth targets for the money stock M1 and subsequently for the monetary base.

Since inflation remained at relatively high levels until 1975, keeping the monetary base more or less constant for over a year amounted to a very restrictive policy indeed. As monetarists would have predicted, inflation began to abate in due course and fell to a low of about 1 percent in 1977 and 1978. However, price stability could be restored only at the cost of a sharp temporary contraction in real activity, which was magnified by the negative effects of the first oil price shock on aggregate demand.

The fight against inflation, at first, was facilitated by a strong appreciation of the Swiss franc, in both nominal and real terms. Considering the relatively low Swiss inflation rate, the SNB was not surprised about the nominal appreciation. On the contrary, it argued that a nominal appreciation of the Swiss franc was essential to insulate the domestic economy from foreign inflationary impulses. ${ }^{2}$ However, the significant real appreciation of the Swiss franc was puzzling. Initially, it probably served to correct distortions accumulated during the period of fixed exchange rates, but as time wore on it increasingly defied economic fundamentals. While the real appreciation supported the SNB's fight against inflation by lowering the prices of traded goods, it undermined the competitive position of domestic industry on the global market. The SNB reacted to the real appreciation of the Swiss franc by relaxing successively monetary policy, especially in 1977 and 1978. As a result, short-term interest rates dropped and approached zero toward the end of 1978. Nevertheless, the real exchange rate continued to increase unabatedly.

\footnotetext{
2 The SNB was certainly aware of Milton Friedman's (1953, especially pp. 180-82) seminal article on the operation of a floating exchange rate system.
}

At the beginning of October 1978, Swiss authorities decided to abandon monetary targeting temporarily and to adopt an exchange rate objective, expressed as a floor on the Swiss franc price of the Deutsche mark. They were compelled to take this course of action because of a looming sharp slump in domestic output. ${ }^{3}$ The interventions that were required to halt the appreciation of the Swiss franc caused a massive expansion in the money supply. Although the SNB switched back to monetary targeting and to a restrictive policy course once calm had returned to the foreign exchange market, it could not help accepting another temporary increase in inflation, to over 7 percent in 1981. Thus, contrary to Friedman's conjecture, the SNB was unable to insulate the domestic economy fully from foreign inflationary shocks. ${ }^{4}$

SNB officials attributed the disastrous real appreciation of the Swiss franc to the willingness of most foreign monetary authorities to tolerate high inflation. In the SNB's view, the Fed's inflationary monetary policy, in particular, served to destabilize the world economy. It prompted private and official international investors to flee U.S. dollar-denominated assets and to shift their funds into stable currencies such as the Swiss franc and the Deutsche mark. If the excessive real appreciation of the Swiss franc had been restricted to the U.S. dollar, however, the SNB would not have been greatly concerned. The really pernicious aspect of dollar weakness lay in the fact that the capital flight also caused a substantial real appreciation of the Swiss franc against the Deutsche mark, the currency of Switzerland's main competitor. For this reason, SNB officials were grateful and relieved when the Fed in October 1979 announced its policy shift. ${ }^{5}$ There is little doubt that the Fed's decision to attack inflation decisively had a salutary effect on the

\footnotetext{
3 By September 1978, the trade-weighted real exchange rate had risen by 50.7 percent above its level of January 1973.

4 See Kugler and Rich (2002) and Rich (2003) for more detailed discussions of this episode. They also explore the question of whether the SNB could have avoided the renewed surge in inflation by following a different policy strategy.

5 Fritz Leutwiler, president of the SNB at that time, gave several speeches on these issues (notably Leutwiler, 1978 and 1979).
} 


\section{Figure 1}

\section{Exchange Rate and Short-Term Interest Rate Differential}

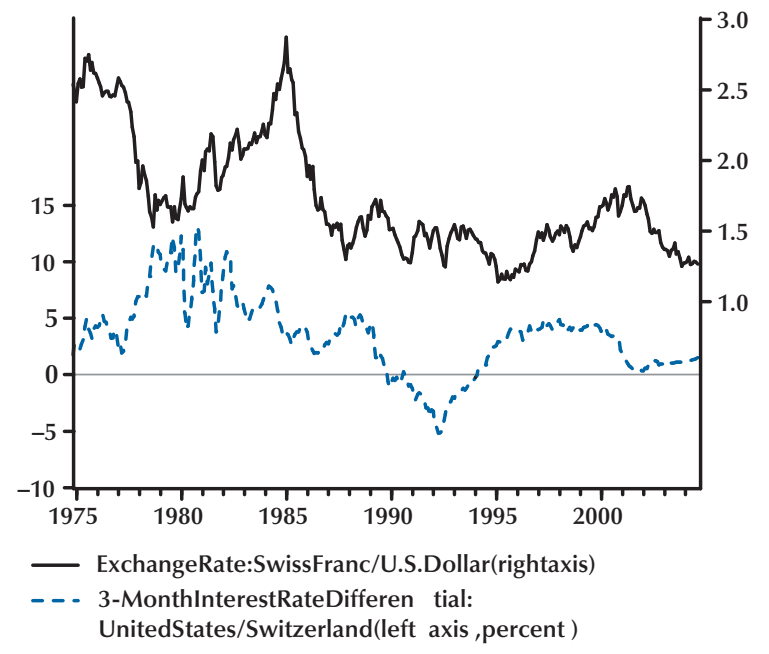

SOURCE: Swiss National Bank. Interest rates quoted on the London euromarket. The data refer to the end of each month.

world economy. Coupled with analogous developments in Europe and other parts of the world, the U.S. policy shift contributed to convincing central banks, governments, and the general public that price stability was essential if an economy was to generate adequate real growth. Thanks to the more stable international monetary environment, central banks, including the SNB, now face a less vexing task of maintaining price stability than they did in the turbulent 1970s.

\section{DOLLAR WEAKNESS AND MONETARY POLICY TRANSMISSION}

Figures 1 and 2 illustrate how the slump in the external value of the U.S. dollar complicated the conduct of Swiss monetary policy. When the SNB adopted monetary targeting, U.S. and Swiss interest rates were more or less identical. However, from 1975 onward, both U.S. short-term interest rates and bond yields rose far above their Swiss counterparts. Therefore, the differentials for the

\section{Figure 2}

\section{Exchange Rate and Bond-Yield Differential}

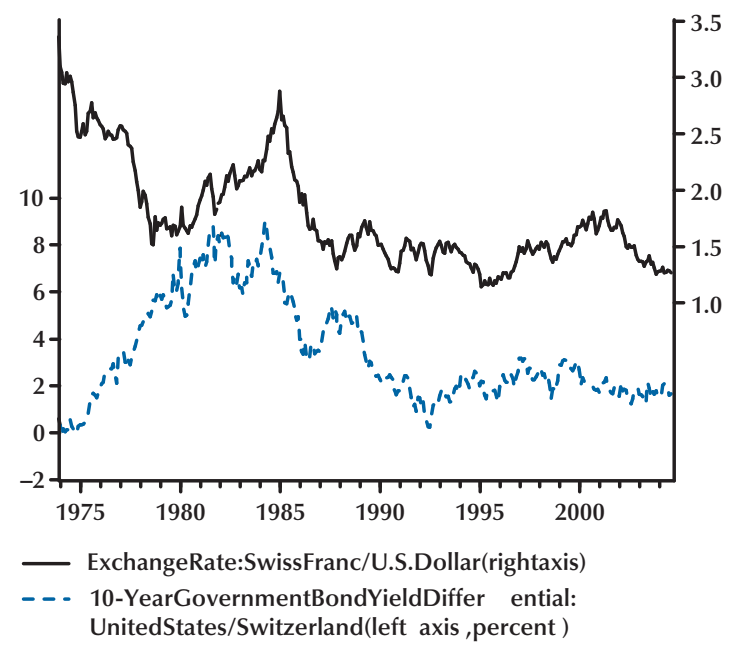

SOURCE: Swiss National Bank. Until the end of 1981, the data refer to the last Monday of each month. If a Monday falls on a holiday, the data for Tuesday are chosen. Thereafter, the data refer to the end of the month.

three-month interest rates and ten-year government bond yields widened considerably. Early in the 1980s, they reached peaks of about 13 percentage points and 8 percentage points, respectively. As may be seen in Figure 3, Swiss short-term interest rates declined quickly after 1975. Since the cyclical contraction in real growth and the moderation of inflation caused the growth in the demand for money to slow significantly, the SNB's efforts to expand the money supply at a steady pace in line with its targets pushed down shortterm interest rates. The relaxation of monetary policy in 1977 and the adoption of a temporary exchange rate target led to a further drop in shortterm interest rates. In the U.S., by contrast, shortterm interest rates remained stable until 1977 and subsequently began to rise, with the increase gathering speed after the policy switch of October 1979 (Figure 4). Even though the interest rate differentials became wider and wider, the Swiss franc price of the U.S. dollar continued to fall. The inverse relationship between the exchange rate and the interest rate differentials persisted until the first half of the 1980s, but thereafter it 


\section{Figure 3}

\section{Swiss Term Structure of Interest Rates}

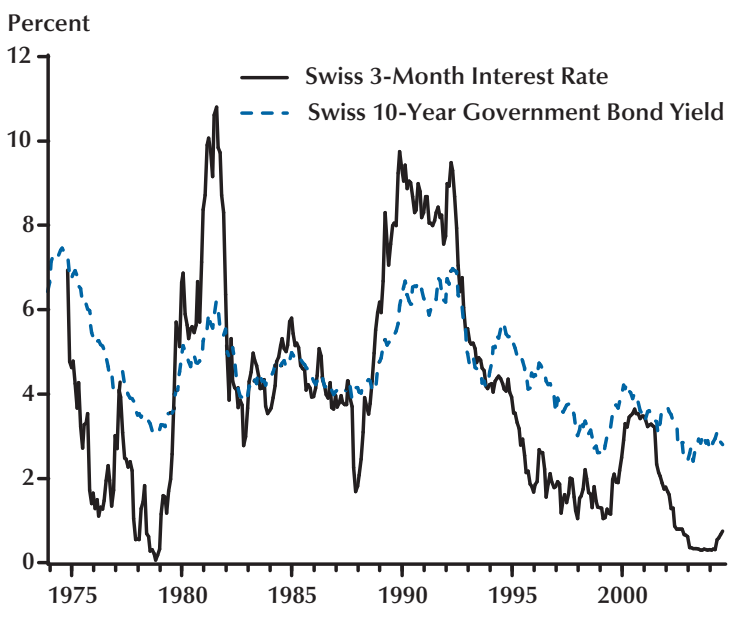

became positive. This relationship-though not very close-has remained positive since, with the exchange rate tending to lag movements in the interest rate differentials. Consequently, the Fed's policy switch altered fundamentally the relationship between the exchange rate and the differentials for short- and long-term interest rates.

The patterns revealed by Figures 1 and 2 are consistent with the SNB's conjecture that in the 1970s a loss of confidence in the Fed caused a flight from the U.S dollar. Since such a shock is associated with a decline in demand for dollardenominated assets and an increase in demand for foreign currency-denominated assets, it should lead to a drop in the exchange rate of the U.S. dollar, as well as a rise in U.S. and a fall in foreign interest rates. Thus, the exchange rate should be negatively correlated with the difference between U.S. and foreign interest rates. However, after 1979, the Fed restored its credibility, and portfolio shifts induced by lack of confidence gradually subsided. As a result, the relationship between the exchange rate and interest rate differentials turned positive and began to look like the patterns predicted by standard macroeconomic models.

The significance of monetary policy credibility is also borne out by Figures 3 and 4. Suppose that a central bank raises short-term interest rates in

\section{Figure 4}

\section{U.S. Term Structure of Interest Rates}

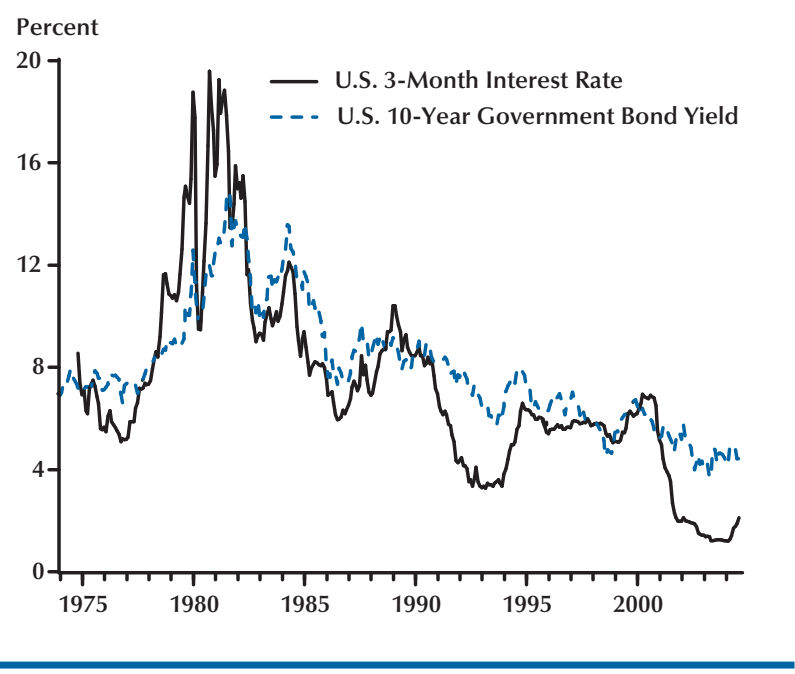

response to an actual or anticipated increase in inflation. If the anti-inflationary policy is credible, the public will expect the increase in short-term interest rates to be temporary. Therefore, long-term interest rates will not go up much. However, if the public is afraid that the future will feature high and persistent inflation, it will demand significantly higher nominal long-term interest rates to protect itself against losses in the real value of its assets. For this reason, long-term interest rates will rise strongly in response to the increase in short-term rates. The Swiss evidence reveals a consistently muted reaction of long-term interest rates to movements in short rates, indicating that monetary policy credibility was never a major problem in Switzerland, not even in the 1970s. In the United States, by contrast, the variance of short- and long-term interest rates was similar until the second half of the 1980s, but thereafter long rates also began to fluctuate less than their counterparts at the short end. Consequently, a comparison of movements in short- and long-term interest rates confirms the earlier conclusion that the Fed gained credibility after the policy switch of $1979 .^{6}$

\footnotetext{
${ }^{6}$ A similar point is made by Goodfriend (2005, p. 247).
} 


\section{CONCLUDING REMARKS}

In this paper I show that the inflationary monetary policy pursued by the Fed up to 1979 exerted destabilizing effects on the rest of the world. In light of Swiss experience, I conclude that the slump in the exchange rate of the U.S. dollar, in particular, complicated considerably the conduct of domestic monetary policy. Despite the adoption of a floating exchange rate, the SNB was unable to insulate the domestic economy completely from foreign inflationary shocks. Only after the U.S. monetary policy switch did the international environment become more conducive to the SNB's efforts of maintaining price stability. My paper also suggests that the restoration of the Fed's credibility impinged on key macroeconomic relationships such as the link between the exchange rate and international interest rate differentials.

\section{REFERENCES}

Friedman, Milton. "The Case for Flexible Exchange Rates," in Milton Freedman, ed., Essays in Positive Economics. Chicago: University of Chicago Press, 1953, pp. 157-203.

Goodfriend, Marvin. "The Monetary Policy Debate Since October 1979: Lessons for Theory and Practice.” Federal Reserve Bank of St. Louis Review, March/April 2005, 87(2, Part 2), pp. 243-62.
Kugler, Peter and Rich, Georg. "Monetary Policy under Low Interest Rates: The Experience of Switzerland in the late 1970s." Swiss Journal of Economics and Statistics, September 2002, 138(3), pp. 241-69.

Leutwiler, Fritz. "Inflation, Exchange Rates and Monetary Policy." Address to the American-Swiss Association, New York, September 27, 1978.

Leutwiler, Fritz. "The Effects of the Reserve Status of a Currency on its Domestic Economy," in Reserve Currencies and other Reserve Assets in International Financial Relations. Luxemburg: Institut Universitaire International (Journées d'Etudes), 1979, pp. 85-103.

Rich, Georg. "Swiss Monetary Targeting 1974-1996: The Role of Internal Policy Analysis.” Working Paper Series No. 236, European Central Bank, June 2003.

Swiss National Bank. Data and Statistics, Monthly Statistical Bulletin. December 2004; www.snb.ch.

\section{APPENDIX}

\section{DATA SOURCES}

Swiss monetary base: Swiss National Bank, 2004, Series B1.

Swiss CPI inflation: Swiss National Bank, 2004, Series O11.

Swiss and U.S. 3-month interest rate: Swiss National Bank, 2004, Series E1 and internal SNB sources. Swiss federal government and U.S. Treasury 10-year bond yields: Swiss National Bank, 2004, Series E3, and internal SNB sources.

Exchange rate: Swiss National Bank, 2004, Series G1. 
